\title{
Political Christianity in Renaissance Drama
}

\author{
Nayef Ali Al-Joulan \\ English Department, Al Al-Bayt University, Jordan
}

Corresponding Author: Nayef Ali Al-Joulan, E-mail: nayef-ali@rocketmail.com

\section{ARTICLE INFO}

\section{Article history}

Received: May 28, 2017

Accepted: July 21, 2017

Published: August 31, 2017

Volume: 8 Issue: 4

Advance access: August 2017

Conflicts of interest: None

Funding: None

\section{Key words:}

Renaissance

Drama,

Christianity,

Politics,

Ideology,

Discrimination

\begin{abstract}
Examining the following selected Renaissance dramas: Marlowe's The Jew of Malta (1585), Shakespeare's The Merchant of Venice (1596), Massinger's The Renegado (1624), Daborne's A Christian Turn'd Turk (1612), and Goffe's The Raging Turk (1656), this research investigates Renaissance dramatists' portrayal of biased Christian standpoints that govern the relation with the non-Christian to uncover whether that dramatization represents the playwrights' participation in validating those attitudes or their critique of politicizing the Christian faith, in both ways underscoring the existence of an ideological 'political faith' issue. It turns out that the period's plays may reveal that such stereotypes are only recruited to further and validate financial gain, political dominance and racial discrimination; that is, political Christianity. However, the playwrights' attitudes remain subject to their unrevealed intentions, and it is, therefore, left to the reader/audience to take sides. Tactically, the dramatists emerge ahead of the Christian and secular politicians of their time as they assume the safe side of impartiality.
\end{abstract}

"A significant part of this research had been carried out during a sabbatical leave granted to the author from Al Al-Bayt University during the academic year 2016-17."

Religion has occupied a position of centrality in literature across ages, whether in terms of faith, propaganda, conflict, or negotiation and dialogue. In Greek traditions, Plato emphasized that literature, mainly focusing on epic and drama, should not misrepresent the gods, whether in terms of transformation, earthly desires, or divine perfection (The Republic). With the emergence of monotheism and at the early stages of Christianity, morality and mystery dramas played a major role in the promotion, celebration, and explication of Christian ideals. 'Mystery' and 'Morality' plays in Middle English literature, the first dealing with what seemed then obscure Christian notions such as Genesis and Crucifixion, and the second with moral Christian values, were recruited to help in creating a graspable and exemplified Christian discourse. However, Chaucer's "Canterbury Tales" represented a shift from that track by presenting the religious figure, a nun or a priest, from a realistic, less-devoted angle. Later on, the Renaissance emerged as an epoch of transition. It witnessed a deviation from the medieval tradition, displaying a rejection of many medieval attitudes towards not only church authority and the nature of the relationship between man or woman and God, but also politics, state and mankind (Falco, 21-2; 206; Bushnell, 9-10; 30-25; 58-61). Both national and religious identities confused and, consequently, faith and politics merged (Pettegree, 18; 21; 24; 30). Hence, various ways transpired to communicate the question of religion, under the influence of an eme gent humanist swerve.

In fact, the revival of classical philosophy, under the influence of a trend that gave prominence to confidence in man's ability to question and determine truth and falsehood, paved the way for the Renaissance humanist intellectual endeavor which recruited a spirit of learning reliant on empirical and rational methods (Bullock, 3; 5; 9; 133-4). This attitude found its way across all disciplines, including faith and theology. Christian humanism hence evolved, putting man's self-fulfillment as a basis for the understanding, practice and adaptation of any Christian value or principle, approaching Christianity as a human-oriented faith (Klemm and Schweiker, 24-9). That is, religious humanists adopted a functional moral definition of religion recognizing the personal and social needs of man, by which religious humanism turned out to be faith functionally practiced, a definition that goes along with the secular humanists' .

Renaissance drama and dramatists cannot and should not be distanced from such context. Many established critical views overlooks the possibility that the Renaissance witnessed a secularization of the drama, and thus a multiplicity of concerns --not just religious ones-- interacted and mutually influenced one another. Therefore, the discussion hereafter explores how major Renaissance dramatists por- 
tray Christian attitudes that govern the relation with the non-Christian other, to move on towards examining whether that dramatization devotedly furthers Christian monopoly or secularly critiques Christian prejudice, the latter being an act of documenting what might be termed 'political Christianity', that of putting the Christian faith to use for political purposes. ${ }^{2}$ Hence, the term 'political' here represents a specific case of ideological bias; namely, exploitation of religion and religious thought to validate racial, economic and political dominance. In particular, the study examines the following representative plays: Marlowe's The Jew of Malta (1585), Shakespeare's The Merchant of Venice (1596), Massinger's The Renegado (1624), Daborne's A Christian Turn'd Turk (1612), and Goffe's The Raging Turk (1656), along with cross-references to other plays.

The dramatization of the religious theme remains a chief characteristic of the Renaissance stage (Beck, 39-40; 47; 70), and it features along with theological, political, and social anxieties against the East. In particular, such dramatization (in the drama of the sixteenth and early seventeenth centuries) should never be separated from the context of the crusades along with conflicts pertaining to clashes and points of difference amongst Jewish and Islamic (notwithstanding Catholic and Protestant) regions, and characters. The treatments of the turned Turk and selfish Jew along with the catholic female might testify to such a claim (Birchwood; Dimmok; McJanet; D’Amico; Patrides). Apart from the intra-Christian clash, the other conflicts might mostly be graspable within oriental and colonial contexts. In his solid Orientalism (1979), the persuasive champion Edward Said brings attention to how the West, in its effort to control the East, creates misrepresentative stereotypes of the Orient and its people. But it is Jonathon Burton who argues the inapplicability of Said's theory to Elizabethan Drama. Nonetheless, the thorough discussions of Nabil Matar valuably develop the propositions of Said which have also flourished in consequent colonial and post-colonial studies. Most recently in 2010a, Abdulla Al-Dabbagh's valuable Shakespeare, the Orient, and the Critics reviews inadequately discussed oriental aspects in Shakespeare's drama to underline how the playwright reverses stereotypes of oriental figures and expresses sympathy to and identification with the alien and the other. Al-Dabbagh's findings pertain to the playwright's camouflaged attitudes a matter which can never negate the documented Renaissance anti-other, particularly anti-Semite, mindset. (See also Al-Dabbagh 2010b).

Muslim, Arab, Turk, Oriental and Jew were othered, misrepresented and antagonized in the Renaissance. During the Renaissance, the community of which was labeled "judeophobic," Jews continued to be rejected and expelled, a policy that started in 1290 under Edward II and lasted until 1656 when they were allowed to return (Burrin, 17). In fact, the Jew is generally representative of the oriental figure on the Elizabethan stage, portrayed with caricatured physiognomy and associated with immoral and irreligious traits (Hales). Marlowe's Barabas and Shakespeare's Shylock are such stereotypes who, David Mirsky argues, have been the models on which the Jewish character has been modeled up toward the twentieth century, mostly as "a monied, cruel, lecherous, avaricious outsider tolerated only because of his golden hoard" and, likewise, the Muslim character as a rash, jealous, irrational, lascivious and barbarian other (17). Daniel Vitkus (1997) argues that "Othello, like the culture that produced it, exhibits a conflation of various tropes of conversion - transformations from Christian to Turk, from virgin to whore, from good to evil, and from gracious virtue to black damnation" (145; see also Watson 1997). Likewise, the terms 'Moor' and 'black' are synonymously used with Semitic figures, including Africans, Indians, and Ethiopians, suggesting, beside dark-skin, pejorative traits (Bartels, 433; OED, "Moor, n2"; Honigmann, 15; Adler, 25). Besides, descriptions of the oriental figure, Jew or Muslim, as treacherous, barbarian, jealous and libidinous are directly related to England's Protestant Reformation's emphasis on pious behavior (Jones; Brownlow; Vozar; Watson 2002). Nonetheless, a closer look at the period's plays may reveal that such stereotypes are merely recruited to further and validate financial gain, political dominance and racial discrimination, particularly when those who adopt and employ those stereotypes are not pious nor are their antagonistic attitudes practiced for the sake of the Christian faith.

To start with, Marlowe's The Jew of Malta (1585) is principally concerned with religion. Mathew Biberman maintains that "the moral universal of the play is, in essence, theological" (25). However, Marlowe's representation of Religion in this play seems to be secular. He dramatizes the negative impact of religion on the potential of a successful relationship among the religiously dissimilar characters of the play as long as they remain chained to view themselves/ each other through religious partiality and biased cultural lenses. Hence, Barabas is subjected to Maltese grudges due to his religion: "Rather had I, a Jew, be hated thus" (I, I, 116). For the same rationale, the Maltese government overtaxes the Jewish merchants on the island to help pay "the ten years tribute" to the Turks (I, ii, 7). Ferneze commands that every Jew shall give half of his state to pay off the tribute or else convert to Christianity. When Barabas debates the injustice of this decision, Ferneze justifies it as an execution of Heaven's orders: "No, Jew, like infidels./Who stand accursed in the sight of heaven,/These taxes and afflictions are befallen" (I, ii, 65-8). The Jews are unfairly required to pay the tribute on the ground of being "infidels" and entangled in Jesus Christ's demise. 1Knight reinforces justice of this abuse: "If your first curse falls heavy on thy head,/'Tis not our fault, but thy inherent sin" (I, ii, 110-12). Here Marlowe exposes the misunderstanding and abuse of religion to validate racism exerted upon Jews for political and economic purposes.

With the enabling force of religion, a successful interaction between Barabas and his host society becomes impossible. The wickedness, sinfulness, and criminality of Barabas turn out to be, as Martin Yaffe suggests, indistinguishable "from his Jewishness" (24). The Maltese's internalization of this religious notion becomes imposing to socially segregate Jews. For example, in the market, no sooner does Katherine, Mathias' mother, see Mathias talking to Barabas, than she deters her son: "Converse not with him, he [Barabas] is cast 
off from heaven./Thou hast thy Crowns, fellow, come let's away" (II, iii, 163-64). The plight of Jews' segregation is not only restricted, as the play suggests, to the Maltese society, it also extends to incorporate other Christian territories. In a revelation of his past experience in Florence, Barabas evokes images of social oppression that Jews experience there. Barabas's monologue, though highlighting the Jew's duplicity and Machiavellian stratagem, echoes obstacles impeding the Jew's social mobility. Barabas soliloquizes: "I learned in Florence how to kiss my hand,/Heave up my shoulders when they call me dog,/And duck as low as any bare-foot Friar" (II, iii, 23-5).

Nevertheless, like the Christian Maltese, Barabas appears to be consumed by religious preoccupations that prevent him from developing a tolerant strategy for integrating into the Maltese society. Barabas disassociates himself from religiously-based social activities in Malta. At the beginning of the play, Barabas proves himself to be cynical of Christian charity; he sees nothing in this religion that deserves his respect (I, i, 118-20). Within the discourse of religion and its impact on shaping identity, the play unveils the way that religion shape Barabas's behavior in response to materialistic gains. Barabas holds a religious contention that his extreme wealth is a sign of Heavenly blessings: "Thus trowls our fortune in by land and Sea/And thus are we on every side enriched:/These are the Blessings promised to the Jews" (I, i, 105-8). This contention impels Barabas to devote his time to gather fortune, a matter that entices the Maltese to view him as an emblem of avarice. Ferneze rebukes Barabas for his desire for gathering fortune: "Excess of wealth is cause of covetousness:/And covetousness, oh "tis a monstrous sin" (I, ii, 126-27). But to Barabas, it "'s no sin to deceive a Christian [Lodowick]" (II, iii, 114). Accordingly, Barabas, the excluded and abused by religion, becomes himself an excluder and abuser of characters in the play by appropriating religion for his own interests, a matter that leads to his failure in making successful communication with the Maltese. Consequently, Marlowe's play portrays financially and socially manipulated faiths on both sides, the Christian and the non-Christian.

Likewise, the dramatization of religion is central in Shakespeare's The Merchant of Venice (1596). Shakespeare seems to critique his people's hypocrisy and their abuse of religion in their interaction with non-Christians. For example, Portia's well-known speech of "[t]he quality of mercy" in the trial scene (IV, i, 182) tells more of the speaker's mercilessness than it does about the addressee, Shylock. The focal point of Portia's speech is to move Shylock to show mercy to Antonio, who is indebted to Shylock for a pound of flesh. To Portia

mercy is above this sceptered sway;

...though justice be thy plea, consider this,

That in the course of justice none of us

Should see salvation. We do pray for mercy (IV, I, 189- 98)

In spite of such an effective preaching about mercy, Portia herself becomes unmerciful to Shylock, and she never exercises what she preaches. When Shylock loses the case under Portia's smart deconstruction of the bond, Portia in- sists on passing a severe sentence on Shylock: a confisc tion of Shylock's half property to the state and the other half to Antonio. Antonio, for his part, is unmerciful to Shylock too. He insists that Shylock bestows all his fortune to Jessica upon his death, and enforces him to turn Christian. Antonio stipulates:

Two things provided more: that for his favor

He presently become a Christian;

The other, that he do record a gift.

Of all he dies possessed

Unto his son Lorenzo and his daughter" (IV, i, 384-88)

Hence, if Shylock epitomizes vengeance and relentlessness, Antonio and Portia do not come out in a better situation. Both characters conspire to strip Shylock of his property and faith. The audience might be sympathetic to Shylock who loses his property together with his faith under Portia's institutionalized power.

Further, Portia's rejection of Morocco on racial, rather than religious, grounds adds to the implicit criticism of the Christian characters' hypocrisy and highlights their race-oriented religious justifications. Worried about having to marry Morocco if he succeeds in selecting the casket that contains her picture, Portia cannot refrain from thinking:

If I could bid the fifth welcome with so good a heart as I can bid the other four farewell, I should be glad of his approach. If he have the condition of a saint and the complexion of a devil, I had rather he should shrive me than wive me. Come, Nerissa.- (to SERVANT) Sirrah, go before. Whiles we shut the gates upon one wooer Another knocks at the door. (I, ii, 121-25)

Morocco chooses wrongly and, relieved, Portia says "A gentle riddance.-Draw the curtains, go,- - Let all of his complexion choose me so" (II, vii, 78-91). Hence, race transcends faith, stressing once again that Renaissance drama reveals Christian characters' treatment of the other to be more race-oriented than faith-bound whereby Christianity turns out to be manipulated by Christians for racially motivated economic, political and social biases. In other words, faith is race-bound. A similar emphasis on puritanical notions marks this relation between Christian and non-Christian figures in Othello where Desdemona's chastity is contrasted to Othello's vulgarity and lasciviousness. Opposed to the description of the oriental figure as a black ram, a lascivious Moor, a foul thief, an enchanter and a circumcised dog, and within a context that underlines the notion of a turned Turk and the general enemy Ottoman, Brabantio's description of Desdemona focuses on issues of purity and beauty, along with natural, biological and physical perfection:

A maiden never bold;

Of spirit so still and quiet, that her motion

Blush'd at herself; and she, in spite of nature,

Of years, of country, credit, every thing,

To fall in love with what she fear'd to look on!

It is a judgment maim' $d$ and most imperfect

That will confess perfection so could err

Against all rules of nature, and must be driven

To find out practises of cunning hell

Why this should be. (I, 3, 94-103) 
Together with this emphasis on chastity and purity, secularized discourse brings nature as the judge of such a relation between Othello and Desdemona. Nature, rather than religion or religious morality, rejects such matching. In addition, political, social, financial and national motives show up as bases for rejecting such marriage. Nevertheless, Othello is grounded in the context of the crusades and is never to be seen away from the clashes and conflicts between Christian and Islamic imperial powers, enmities that continued to grow and be of concern for dramatists.

Towards the end of the Renaissance, Islam became an integral part of the dramatists' debate on religion. Islam and Muslim became objects of distortion and emblems of threat to the religious identity of the West in the works of late Renaissance, an attitude that was manipulated to offer pretexts for actions rising from Western political and psychosocial anxieties against the East. Massinger's The Renegado (1624) is designed to give a distorted image of Islam and its representatives. Such a distortion might be considered within the context of the strategy the early seventeenth-century English writers assumed to encounter the wave of Christians turning Muslims, an issue that was viewed by Renaissance dramatists as a real threat to Europe's religious identity. Nabil Matar (1999) maintains: "converts to Islam so grew in number that English as well as continental dramatists, hack writers, and poets felt the need to examine the renegade in their work" (490; see also Matar 1994, 35). To counter this religious dilemma, Massinger directs his thought toward attacking Islam and its representatives, emphasizing the falsehood of Islam and the corrupt life of its people. Such ends require Massinger to take his audience in an imaginary journey to the Islamic interior where his trio heroes, Vitelli, Gazet, Vitelli's servant, and Francisco, a Jesuit, become first hand witnesses to the corruption of Islam and the perverted life it enhances. The trio heroes are bound in a secret mission to save the Venetian, chaste virgin, Paulina, who was abducted by the convert, Grimaldi, and sold to Asambeg as a slave. Consequently, Muslim characters, be them males or females, are depicted as extravagant pursuers of sexual gratification (John, 333-5; Murray, 27-30; Clark, 85-8; Jowitt, 49, 66, 170, 175, 180). The Turkish ladies' "insatiable lust" misleadingly makes them objects of repugnant animal imagery. When Francisco and Vitelli reach Tunis, Francisco becomes obsessed with the idea that the physical charms of the young attractive Vitelli would make him very vulnerable to the overpowering temptations of the lustful, animalistic Turkish "dames". Thus, Francisco warns him of such an intended danger:

\section{...these Turkish Dames}

Like English mastiffs.

If lust once fire their blood

The fiends themselves would shake a

To enjoy their wanton ends. (I, iii, 7-13).

What strikes in Massinger's perpetuation of this notion is that he associates it with Islam. The play points out that Islam embrace all sorts of sexual gratification, especially for men. During her talk with Grazie about the discrepancy between the freedom of English ladies in comparison with the confinement of Muslim ladies, Donusa regrets lacking such autonomy: "We enjoy no more/That are of the Ottoman race, though our religion/Allows all pleasure" (I, ii, 48-50).

Indeed, the notion that Islam celebrates and reveres sensuality is a long standing tradition in Western literary writings. In his essay, "Turning Turk in Othello," Vitkus (1997) asserts:

In Western European texts, from the Medieval to the early period, Islam was usually defined as a licentious religion of sensuality and sexuality. A long tradition standing of anti-Islamic polemic denounced the religion of Mahomet as a system based on fraud, lust, and violence. (156)

Massinger emphasizes the superiority of Christianity over Islam. His dramatization of Paulina's capacity to protect herself from Asambeg's sexual advances signals this point. In spite of being a captive, very vulnerable to Asabeg's possible sexual violence, Paulina, on account of the magical relics she keeps and the prayers she performs, succeeds in protecting her chastity. Asambeg contemplates his powerlessness before Paulina: ". there is something in you/ That can work miracles, or I am cozened" (II, v, 149-50). Paulina's power, which is produced by spirituality, functions as magnetic, perhaps hypnotic, dramatic swerve to revive the spectators' faith in their religion. Having in mind Renaissance dramatists' abundant representation of religiously-prohibited perverted sexual behavior in their community, one may safely relate Massinger's biased attribution of sexual misconducts to Islam to political motivations. As Mustafa Sahiner sees it, Massinger's misrepresentation of sexuality in Islam was part of a general fear by the state and religion that Christians might turn Turks for the sake of sexual pleasure and, therefore, "Many precautions were taken by stage and religious authorities in England in order to prevent conversions through marriage" (106)

Like Massinger, Daborne misrepresents Islam and Muslims in A Christian Turn'd Turk (1612). Daborne appears to be overwhelmed by the threat Islam forms against the religious identity of his people. Daborne's Ward contemplates the continuous threatening power of Islam on the English people's life and religion: "The slavery of man, how this religion rides us/Deprives us of our freedom from our Cradles/Ties us in superstitious bondage (I, vii, 201-03). Here Ward points to the aggravating problem of conversion and, simultaneously, asserts the falsehood of this rival religion. Daborne's perpetuation of Islam as superstitious creed goes in line with his perception of its believers as lascivious and immoderately lustful beings (Hoenselaars, 173). Benshaw, the Jewish merchant in Tunis, decides to pretentiously convert to Islam to protect his wife from the sensual transgressions anticipated from the lustful Turks who are, as the play insinuates, used to committing such criminal act especially against the non-Muslims' wives (I.vi.73-6). To Rabshake, Benshaw justifies his conversion: "Tush, my wife man, thou hast forgot how dear/I. turned Turk, all to keep My bed free from these Mahometan dogs" (I, vi, 73-6). Daborne's display of Benshaw's anxiety against Muslim Turks' promiscuity accentuates the hostile environment of living among Muslims, a motif perpetuated by Daborne to dissuade the possible converts to Islam. Throughout the play, Daborne 
underlines the convert's risky life among the Turks, highlighting the convert's dignity, as in Benshaw's case, and the trauma and distress resulting from his moral degeneration and loss of his faith. Wrad's story of piracy and conversion features such trauma. In spite of the wealth, protection and authority he gains from being a pirate and convert in Tunis, Ward keeps lamenting such transformation in his life (I, vii, 274-77) and his despair culminates in his tragic suicide at the end of the play. This misrepresentation culminates later in Goffe's The Raging Turk (1656), where paganism becomes a synonym for Islam. Goffe misleadingly fashions the Turkish characters as pagans invoking mythological idols. Achomates is shown in the battle against Zemes and the Armenian king invoking Mars to grant him power and vigor: ". thou propitious Mars,/Rough god of warre: steele vp this wearie arme,/and put fold vogor in my bones" (II, iii, 594-96). In another reference, Selymus, dismayed by his father's decision to assign Prince Corcutos to rule in "rich fonia," says his prayers to Pluto to bless him with political shrewdness to get to the Turkish throne (II, iv, 110-16). Such allusions to the Turks' paganism should have been effective enough to mislead the spectators to draw an image of Islam as a heathen religion (Floyd-Wilson; Mehl, 24). As Fredson Bowers puts it, "Goffe appears to be fascinated with the reputed evil of the Turks and their insatiable greed" (157). Such a claim might be attributed to Goffe's educational and professional background as a student of divinity and a licensed preacher and dean of Christ Church (Godwin in ODNB, 70-71).

Consequently, one can see that the religious theme in the drama of the sixteenth and early seventeenth centuries is closely associated with political, social, and theological anxieties that dominated the relationships between the West and the East. However, one cannot assure that such a treatment of religion represents a secularized attitude on the dramatists' behalf for one may not be able to deny the playwrights' religious bias. But one may argue that the sixteenth and early seventeenth-centuries dramatists merely report the reality of their communities, since they perceive life as macrocosmic play: "Life's but a walking shadow, a poor player/That struts and frets his hour upon the stage" (Macbeth, V, 5, 28-9); "All the world's a play/And all the men and women merely players" (As You Like It, II, 7, 140-1). Such an attitude underscores that drama is a representation of life, reflecting hence the attitudes of the people of that time rather than showing the playwright's own opinion. And being distanced, the playwright is thus seemingly detached from the religious attitude of the time which the characters reflect or adopt. As such, the dramatist appears as an objective observer and reporter. As Neil Keeble persuasively argues, at that time of powerful religious discourse, it was difficul to openly swim against the current and writers had to safely communicate their views (82). There was no official approval for toleration towards the non-Christian (Sell and Johnson, 4). Nonetheless, the attitude of Renaissance dramatists toward religion is evolutionary and reveals wider inter-faith and inter-culture disputes, differences, rivalry, angst, and uneasiness. Religious pretexts are manipulated in the discourse of the sixteenth and early seventeenth-centuries drama in order to verify, justify and validate the nonreligious bases of the relationships between the Christian West and the non-Christian other. The playwrights might have shared in conducting that manipulation but they can also be considered to have only unfavorably reported that was performed by the community.

However, some dramatists, like Marlowe, in The Jew of Malta, and Shakespeare, in The Merchant of Venice and Othello, seem to promote the notion of rejecting religion as a basis for establishing relationships amongst people. Therefore, Shakespeare's aforementioned assessment of life being a play comes along with his assertion of the hollow meaning of life and, indirectly, divine authority, " it is a tale/Told by an idiot, full of sound and fury,/Signifying nothing" (Macbeth, $\mathrm{V}, 5,30-2)$, a secular attitude indeed. It is in dramas such as these that the sixteenth and early seventeenth-centuries playwrights provide a rationale to argue for a secular attitude towards the non-Christian in Renaissance drama, for here one finds dramatists who perhaps "identify with, and give sympathetic voices to, social outsiders and misfits; most notably, but by no means only, Jews (Shylock), [and] 'Moors' (Othello)" (Rist, 121). As John Russell Brown argued in the case of The Merchant of Venice, Shylock's speech (III, i, $58 \mathrm{ff}$ ) is powerful enough to make one forget that a "villain is speaking" (xi). The fact that Shakespeare portrays Shylock as a master of eloquence should not be overlooked; most fl ently, Shylock says:

Hath not a Jew eyes? Hath not a Jew hands, organs,

Dimensions, senses, affections, passions; fed with

The same food, hurt with the same weapons, subject

To the same diseases, heal'd by the same means,

Warm'd and cool'd by the same winter and summer

As a Christian is? If you prick us, do we not bleed?

If you tickle us, do we not laugh? If you poison us,

Do we not die? And if you wrong us, shall we not revenge?

If we are like you in the rest, we will resemble you in that.

If a Jew wrong a Christian, what is his humility?

Revenge. If a Christian wrong a Jew, what should his

Sufferance be by Christian example? Why, revenge.

The villainy you teach me, I will execute,

And it shall go hard but I will better the instruction. (III, i, 58ff)

Shylock's expressiveness and persuasiveness foreground the painful experience he is made to undergo under the over-Christianized discourse of the Elizabethan community and hint at Shakespeare's emphasis on presenting him as a tragic hero, a matter that some critics emphatically proposed, as with Harold Bloom who asserts that "Shylock's shrewd indictment of Christian hypocrisy [delights us, but]... Shakespeare's intimations do not alleviate the savagery of his portrait of the Jew" (24) and James Shapiro for whom the play "scrapes against a bedrock of beliefs about the racial, national, sexual, and religious differences of others" (228). Likewise, John Gillies argues that Shakespeare's representation of Othello challenges the racist responses of the later critics and, one may add, the critics and people of the time (32-3). In fact, Shakespeare was aware of the use of religion as a 
pretext for non-religious goals. In The Merchant of Venice he eloquently and directly reveals:

The devil can cite Scripture for his purpose.

An evil soul producing holy witness

Is like a villain with a smiling cheek,

A goodly apple rotten at the heart.

O, what a goodly outside falsehood hath! (I, iii, 97-101)

Rather than attacking religion (Christianity) openly, Shakespeare points to a misuse of religion by those whom he calls 'the devil'. Though seemingly attributed to particular people, the statement seems to imply a much wider context, a community living under Christian ideals manipulated by political deceit and falsehood.

Likewise, in The Jew of Malta, Barabas asserts that his acts of treachery emulate Christianity, since Catholic teachings maintain that "Faith is not to be kept with heretics" when "all are heretics that are not Jews" (II, iii, 311-12). In fact, it was considered heretical to convert to another faith and Judaism and Islam were considered the most undesirable faiths (Vitkus 2003, 145; see also Vitkus 1999, Matar 1998 and Matar 2005). Barbas's rhetoric here echoes Shylock's famous "Hath not a Jew eyes?", outlined earlier. Besides, Christian characters are satirically presented in the play; monks and nuns perform prohibited sexual behavior and friars outbid one another to confiscate Barabas's wealth. Above all, each of the three religious groups presented in the play (Christians, Jews, and Muslim Turks) exclusively claims religious morality which entitles each of them to antagonize the other. As such, the play critiques religious hypocrisy at large. Marlowe himself seems to offer a more secularized attitude in Tamburlaine, where a more distant attitude on the playwright's part seems evident, dramatizing Judaism, Christianity, and Islam in a context of negotiation and dialogue.

Nonetheless, Marlowe doubtlessly criticizes religious narrow-mindedness which leads to chauvinism and intolerance, including Christian bigotry. In Dr Faustus, Marlowe says:

What doctrine call you this? Che sarà, sarà:

What will be, shall be! Divinity, adieu!

These metaphysics of magicians,

And necromantic books are heavenly! (1.40-50)

Mockingly, Faustus chooses amongst different disciplines to get the highest source of knowledge. He selects religion and as he starts reading the Bible he finds that Christianity promises no more than death, a religion of and for the magicians who allege communication with dead. Hence, in The Jew of Malta Marlowe attests: "MACHEVILL: I count religion but a childish toy,/And hold there is no sin but ignorance" (prologue 14-15). Christian anti-other discourse is no more than a game played by politicians to gain public opinion and loyalty. It is no more than a mechanism by which to hide political and economic prejudice "BARABAS: For religion/Hides many mischiefs from suspicion" (I, ii, 279-280).

As in the case of the so-called 'political Islam' of today's world, the Christian faith was exploited in the sixteenth and early seventeenth centuries for political, economic, and racial motives, a matter Renaissance drama successfully reveals. The Western societies and governments of that time recruited Christian sentiments to validate opposition to the non-Christian other, and sometimes to the Christian other. Nonetheless, the drama of the sixteenth and early seventeenth centuries might be seen as having actively perpetuated that act of politicizing Christianity to endorse political, economic, and racial stratagems against the 'other', or liberally, secularly, and prejudicially-free reported, perhaps even censored and falsified, that stance and the subterfuges it recruited. As such, Renaissance drama and dramatists have either subjectively shared in or objectively documented Western societies' employment of Christianity for political purposes. Both attitudes are political, but the earlier is more rooted into religious bias and hypocrisy, whereas the latter is secular and reflective of conservative views against Christian prejudice, where the act of uncovering such Christian contentions may reveal a secular critique of religion's racist nature, as it points at man's selfish manipulation of faith for political, economic, social or other predispositions. The playwrights' attitudes are subject to their unidentified intentions and it is, therefore, left to the reader/audience to take sides. Politically speaking, such ambiguity safeguards the dramatists before both sides and puts them ahead of the religious and secular politicians of their time. Nonetheless, it underscores the existence of an ideologically-motivated case of political Christianity.

\section{ENDNOTES}

1. Other types of humanism developed thereafter, including Western cultural humanism, Modern (also termed Natu-ralistic, Scienti ic, Ethical, Democratic) humanism, dis-believing in the supernatural and relying mainly on rea-son and science, as well Secular humanism, motivated by eighteenth-century enlightenment and nineteenth-century free thought Nonetheless, religious humanism remained valid since a general controversy kept underlying all these types of humanism on whether such ways of thought were religious or not (Edwords; see also Holyoake, p. 50, Wal-ter, p. 43 and Kurtz, p. 8)

2. See Coleman (2007) for a full account of how scholarship mostly stressed the importance of religion as a context for Renaissance drama and ignored an emerging seculariza-tion of thought by institutional structures at the time.

3. One should not overlook the indebtedness of the Renais-sance to the Middle Ages: not in terms of discussion but awareness. The "religious" and the assumption that some plays are interested in religion (in general) might seem either puzzling or obvious. Texts are often immersed in the symbolic system. Hence, Catholicism (perhaps "old faith" would make more sense), the Puritans, Reform etc. are treated under the generalized notion of Christianity since it is not intended here to venture into making clear proper distinctions among Christian sects and rather draw attention to general politicized antioriental faith-rooted attitudes. Therefore, the essay deals with representative selections to highlight an issue that requires a much wid-er, further, and more comprehensive research.

4. No wonder that twentieth and twentieth-first centuries Western (mostly British) propaganda of the so-called 'war on terror' has frequently made recourse to sixteenth-cen-tury drama to express and validate antagonism against an ethnic other who represented cultural and life threats (Coleman 2008). 
Acknowledgement: The idea of this article was initially provoked by a graduate research paper on the spiritual theme in the Renaissance by Dr. Mohammad Salim Al-Mustafa (Ph.D. candidate at the time) which I proofread and revised in 2010. I here argue against Al-Mustafa's paper in that rather than spiritual, Christian discourse is politically and ideologically motivated in Renaissance Drama. Hence, verses discussed in Al-Mustafa's paper are here reread and rethought from a different angle.

\section{REFERENCES}

Adler, D.S. (1974). "The Rhetoric of Black and White in Othello" Shakespeare Quarterly, 25(2), 248-257.

Al-Dabbagh, A. (2010a). Shakespeare, the Orient, and the Critics. New York: Peter Lang.

Al-Dabbagh, A. (2010b). Literary Orientalism, Postcolonialism, and Universalism. New York: Peter Lang.

Bartels, E. C. (1990). "Making More of the Moor: Aaron, Othello, and Renaissance Refashioning of Race." Shakespeare Quarterly, 41(4), 433-54.

Beck, B. (1987). From the Rising of the Sun: English Images of the Ottoman Empire to 1715. New York: Peter Lang.

Bevington, D., and Eric, R. (eds.). (1995). Doctor Faustus and Other Plays. Oxford: Oxford UP.

Biberman, M. (2004). Masculinity, Anti-Semiticism, and Early Modern English Literature from the Satanic to the Effeminate Jew. Burlington: Ashgate Publishing Limited.

Birchwood, M. (2007). Staging Islam in England, Drama and Culture, 1640-1685. Rochester: Boydell.

Bloom, Harold (ed.) (2008). William Shakespeare's The Merchant of Venice. New York: Bloom's Literary Criticism.

Bowers, F. (ed.). (1987). "Thomas Goffe." In Dictionary of Literary Biography. Vol. 58: Jacobean and Caroline Dramatists. Gale: U of Virginia P: 115-122.

Brown, J.R.(ed.) (1961). The Merchant of Venice. London: Methuen, 3rd. rpt.

Brownlow, F. W. (1979). "Samuel Harsnett and the Meaning of Othello's 'Suffocating Streams"'. Philological Quarterly. 58: 107-115.

Bullock, A. (1985). The Humanist Tradition in the West. London: Norton.

Burrin, Ph. (2005). Nazi Anti-Semitism: From Prejudice to Holocaust. Trans. Janet Lloyd. New York: The New P.

Burton, J. (2005). Traffic and Turning: Islam and English Drama, 1579-1624. Newark: U of Delaware P.

Bushnell, R. (1990). Tragedies of Tyrants: Political Thought and Theater in the English Renaissance. Ithaca: Cornell UP.

Clark, S. (1994). The Plays of Beaumont and Fletcher: Sexual Themes and Dramatic Representation. New York and London: Harvester Wheatsheaf.

Coleman, D. (June 2008). Ireland and Islam: Henry V and the "War on Terror". Shakespeare, 4(2), 169-180.

Coleman, D. (November 2007). "Recent Studies in Religion and Renaissance Drama," Literature Compass. 4:6: 1612-1624. Available at: http://onlinelibrary.wiley. com/doi/10.1111/j.1741-4113.2007.00499.x/abstract

D’Amico, J. (1991). The Moor in English Renaissance Drama. Tampa: U of South Florida P.

Daborne, R. (2000). A Christian Turn'd Turk. In Vitkus (ed.). Dimmok, M. (2005). New Turks: Dramatizing Islam and the
Ottomans in Early Modern England. Aldershot: Ashgate.

Edwords, F. (1989). “What Is Humanism?". American Humanist Association. Retrieved 25 March 2017. Available at: https://americanhumanist.org/what-is-humanism/edwords-what-is-humanism

Erne, L. (2001). Beyond the Spanish Tragedy: A Study of the Works of Thomas Kyd. Manchester: Manchester UP.

Falco, R. (2008). Charismatic Authority in Early Modern English Tragedy. Michigan: John Hopkins UP.

Floyd-Wilson, M. (2003). English Ethnicity and Race in Early Modern Drama. Cambridge: The P of Syndicate of the U of Cambridge.

Gillies, J. (1994). Shakespeare and the Geography of Difference. Cambridge: Cambridge UP.

Godwin, W. (1917). "Goffe or Gough, Thomas." Oxford Dictionary of National Biography. 8, 70-71.

Goffe, T. (1656). The Raging Turk, or, Bajazet the Second: a Tragedie. 2nd ed. London: G. Bedell and T. Collins. Available at: http://openlibrary.org/works/OL6815961W/ The_raging_Turk_or_Bajazet_the_Second

Hales, J. W. (1894). "Shakespeare and the Jews." The English Review. IX: 652-61.

Hoenselaars, A. J. (1992). Images of Englishmen and Foreigners in the Drama of Shakespeare and His Contemporaries. Madison/Teaneck, NJ: Fairleigh Dickinson UP.

Holyoake, G. J. (1896). The Origin and Nature of Secularism. London: Watts \& Co.

Honigmann, E. A. J. (ed.) (1997). Othello. London: Thomas Nelson.

John, C. (2009). "Fletcher, Massinger, and Roman Imperial Character." Comparative Drama, 43(3), 317-54.

Jones, E. (1971). Othello's Countrymen. Charlottesville: $\mathrm{U}$ of Virginia $\mathrm{P}$.

Jowitt, C. (2002). Voyage Drama and Gender Politics, 15891642: Real and Imagined Worlds. Manchester UP.

Keeble, N. 1987. The Literary Culture of Nonconformity in Later Seventeenth-Century England. Leicester: Leicester UP.

Klemm, D., and Schweiker, W. (2008). Religion and the Human Future: An Essay in Theological Humanism. United Kingdom: Wiley-Blackwell.

Kurtz, P. (1995). Living Without Religion: Eupraxophy. Amherst, NY: Prometheus Books.

Marlowe, Ch. (1995). The Jew of Malta. In Bevington and Rasmussen (eds.).

Massinger, P. (2000). The Renegado. 1624. in Vitkus (ed.).

Matar, N. (1998). Islam in Britain: 1558-1685. Cambridge UP.

Matar, N. (1999). Turks, Moors, and Englishmen in the Age of Discovery. New York: Columbia UP.

Matar, N. (2005). Britain and Barbary: 1589-1689. UP of Florida.

Matar, N. (January 1994). "Turning Turk: Conversion to Islam in English Renaissance Thought." Durham University Journal, 86, 33-42.

McJanet, L. (1996). "Mapping the Ottomans on the Renaissance Stage." Journal of Theater and Drama 2: 9-34. 
Mehl, D. (1965); (repr. 1982). The Elizabethan Dumb Show: The History of a Dramatic Convention. London and New York: Meuthuen.

Mirsky, D. (1970). "The Fictive Jew in the Literature of England 1890-1920." In Gersion Appel, Morris Epstein \& Hayim Leaf. Samuel K. Mirsky Memorial Volume. New York: Sura/Yeshiva University: 221-237.

Murray, J. (2004). "Masculinizing Religious Life: Sexual Prowess, the Battle for Chastity and Monastic Identity," in Holiness and Masculinity in the Middle Ages. Eds. K. J. Lewis and P. Callum. Cardiff: University of Wales Press: 24-42.

Patrides, C.A. (1963). “The Bloody and Cruel Turke': The Background of a Renaissance Commonplace." Studies in the Renaissance, 10, 126-35.

Pettegree, J. (2011). Foreign and Native on the English Stage, 1588-1611: Metaphor and National Identity. London: Palgrave Macmillan.

Rist, T. (2009). "Shakespeare Now and Then: Communities, Religion, Reception.” In Eds. Sell and Johnson: 109-26.

Sahiner, M. (2007). "The Problematic of 'Turning Turk' in Philip Massinger's The Renegado". Journal of British Literature and Culture. 14, 79-91.

Said, E. (1979). Orientalism. New York: Pantheon.

Sell, R. D. and Johnson, Anthony (eds.) (2009). Writing and Religion in England, 1558-1689: Studies in Community-Making and Cultural Memory. London: Ashgate Publishing ltd.

Shakespeare, W. (1998). The Merchant of Venice. In The Arden Shakespeare Complete Works. Arden.

Shakespeare, W. (1998). Othello. In The Arden Shakespeare Complete Works. Arden.
Shapiro, J. S. (1996). Shakespeare and the Jews. New York: Columbia UP.

Shell, A. (1999). Catholicism, Controversy, and the English Literary Imagination, 1558-1660. Cambridge: Cambridge UP.

Vitkus, D. (ed.). (2000). Three Turk Plays from Early Modern England. New York: Columbia UP.

Vitkus, D. J. (1997). "Turning Turk in Othello: The Conversion and Damnation of the Moor" Shakespeare Quarterly, 48(2), 145-176.

Vitkus, D. (1999). "Early Modern Orientalism: Representations of Islam in Sixteenth and Seventeenth-Century Europe" In eds. D. Blanks and M. Frassetto. Western Views of Islam in Medieval and Early Modern Europe. NY: St. Martin's P: 207-30.

Vitkus, D. (2003). Turning Turk: English Theater and the Multicultural Mediterranean, 1570-1630. Palgrave.

Vozar, T. M. (2012). "Body-Mind Aporia in the Seizure of Othello." Philosophy and Literature, 36(1), 183-86.

Walter, N. (1997). Humanism: what's in the word? London: RPA/BHA/Secular Society Ltd.

Watson, R. N. (1997). "Othello as Protestant Propaganda." In eds. Claire McEachern and Deborah Shuger. Religion and Culture in Renaissance England. Cambridge: Cambridge UP: 234-57.

Watson, R. N. (2002). "Othello as Reformation Tragedy.” In eds. Thomas Moisan, Douglas Bruster, and William H. Bond. The Company of Shakespeare: Essays on English Renaissance Literature in Honor of G. Blakemore Evans. Madison, NJ: Associated UP: 65-96.

Yaffe, M. D. (1997). Shylock and the Jewish Question. Baltimore: Johns Hopkins UP. 